\title{
Development of an economic mechanism for creating sustainable regional infrastructure for supporting small businesses
}

\author{
Saule Rakhimova ${ }^{1}$, Lyudmila Goncharenko ${ }^{1}$, Aleksey Titkov $^{2}$, Sergey Sybachin ${ }^{1}$, and \\ Kymbat Kunanbaeva ${ }^{3, *}$ \\ ${ }^{1}$ Plekhanov Russian University of Economics, 117997, Moscow, Stremyanny lane, 36, Russia \\ ${ }^{2}$ Toraighyrov University, 140008, Pavlodar, Lomova str., 64, Republic of Kazakhstan \\ ${ }^{3}$ Financial University under the Government of the Russian Federation, 125993, Moscow, \\ Leningradsky prospect, 49, Russia
}

\begin{abstract}
This article was prepared as part of the government contract as requested by the Ministry of Science and Higher Education of the Russian Federation on the subject formulated as «Structural changes in economy and society as a result of achieving the target indicators of National projects, which provide opportunities to organize new areas of social and economic activity, including commercial, both in Russia and abroad» (project No. FSSW-2020-0010).
\end{abstract}

\section{Introduction}

The development of an innovative infrastructure for supporting entrepreneurial activity in the regions should presuppose the creation of appropriate organizational and economic foundations.

When developing ways for improving infrastructure support for business, small enterprises, the main strategic guidelines should be focused on a qualitative increase in the level of entrepreneurial activity of the population of the region and on improving the quality of the structure of human resources involved in the implementation of entrepreneurial ideas and business projects.

As studies show, one of the reasons for the problems of the insufficient level of entrepreneurial activity of the population of the regions is a systemic problem - the presence of reserves in the development and improvement of the regional infrastructure for supporting entrepreneurship.

\section{Materials and Methods}

To improve and develop infrastructural support for entrepreneurial activity in the regions, an appropriate economic model can be proposed, which includes a number of interrelated organizational elements, which are shown in Figure 1.

\footnotetext{
* Corresponding author: kunanbaeva_kymbat@mail.ru
} 


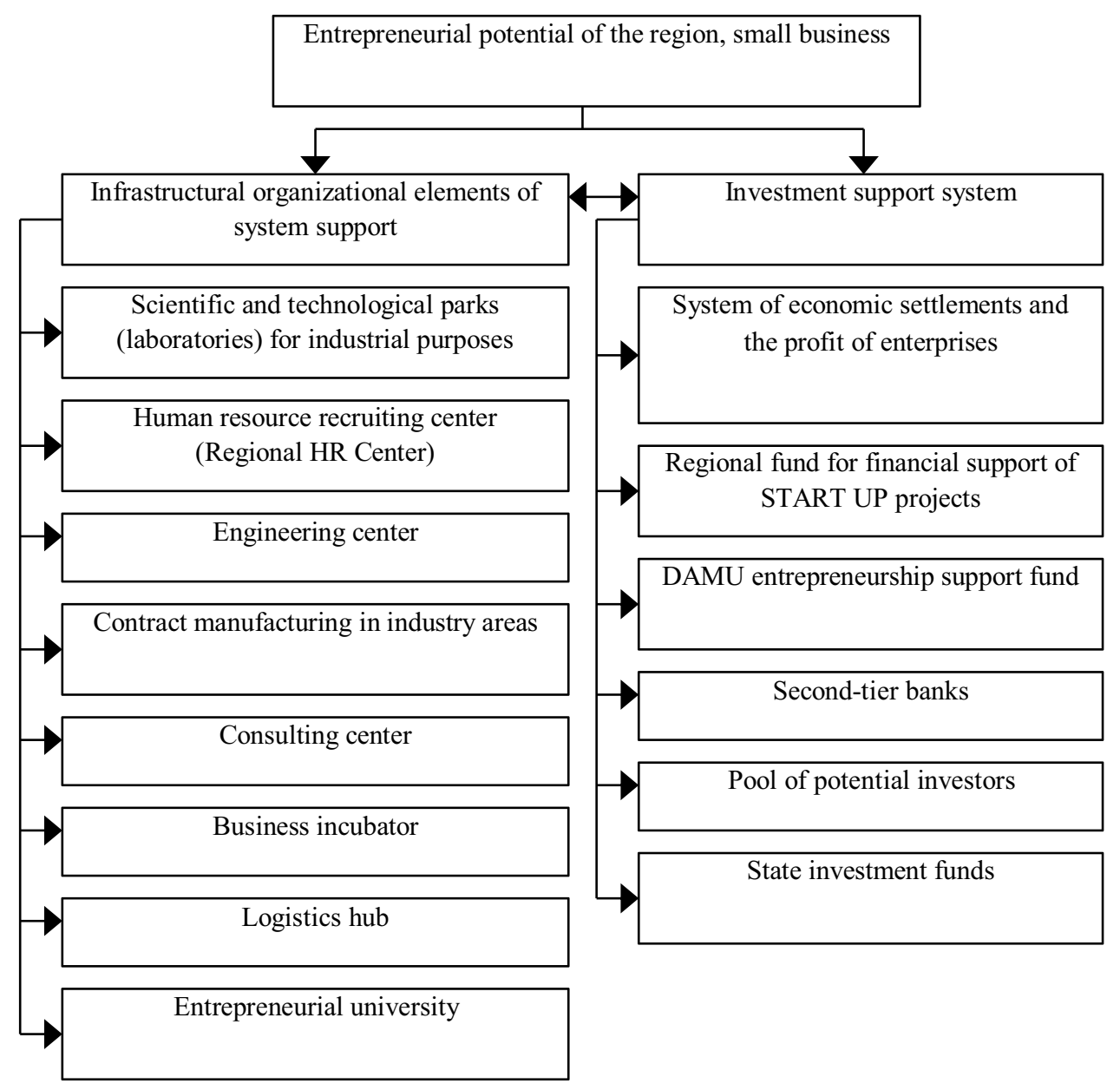

Fig. 1. An economic model for building a comprehensive and balanced infrastructure to support regional entrepreneurship.

In the system of functioning and realization of the entrepreneurial potential of the regions, the following infrastructural elements, which are absent at the present stage, can be applied in practice:

- scientific and technological parks (laboratories) for industrial purposes;

- human resource recruiting center (Regional HR Center);

- engineering center;

- contract manufacturing in industry areas;

- consulting center;

- business incubator;

- logistics hub.

The activities of scientific and technological parks (laboratories) for industrial purposes should be aimed at intensifying innovation processes in priority sectors of the economy:

- petrochemistry;

- metallurgy;

- mechanical engineering;

- processing of agricultural products in the agro-industrial complex.

Scientific and technological parks for industrial purposes should be modern specialized high-tech laboratories for performing all types of research and development work. These 
regional technoparks must be of a public nature, and all business entities can be their residents.

The activities of the human resources recruiting center (Regional HR Center) will be focused on the arrangement, selection of highly qualified personnel for the implementation of regional innovative projects. The main goal of creating such a center is to qualitatively improve the structure of HR resources involved in scientific research and the implementation of innovative projects. The methodology for the functioning of the HR center will be to confirm the skills, knowledge and competencies of potential applicants for vacant jobs.

The main tasks of the operation of the engineering center will be focused on providing a wide range of engineering services to enterprises, including small and medium-sized businesses. Engineering services will be provided in such areas as:

- performance of engineering and technical calculations for the launch of innovationoriented industries;

- delivery and installation of the main innovative technological equipment;

- implementation of measures to launch new production facilities and train production personnel.

Contract manufacturing can become a unique element focused on the development of innovative entrepreneurship. It can be based on a number of existing industrial production facilities shown in Figure 2.

The activities of contract manufacturing will be focused on the production of custommade products from small enterprises implementing innovative START UP projects at the facilities of independent regional manufacturers who will be able to ensure full compliance with the technological cycle and quality control of finished products in accordance with the requirements of innovative customer enterprises.

The introduction of contract manufacturing into regional practice will allow small innovative entrepreneurial structures to produce their own products, without creating a special expensive and capital-intensive production base.

In addition to the above-mentioned elements of the infrastructure of entrepreneurial support, centers of advisory support can be created - a consulting center and a business incubator.

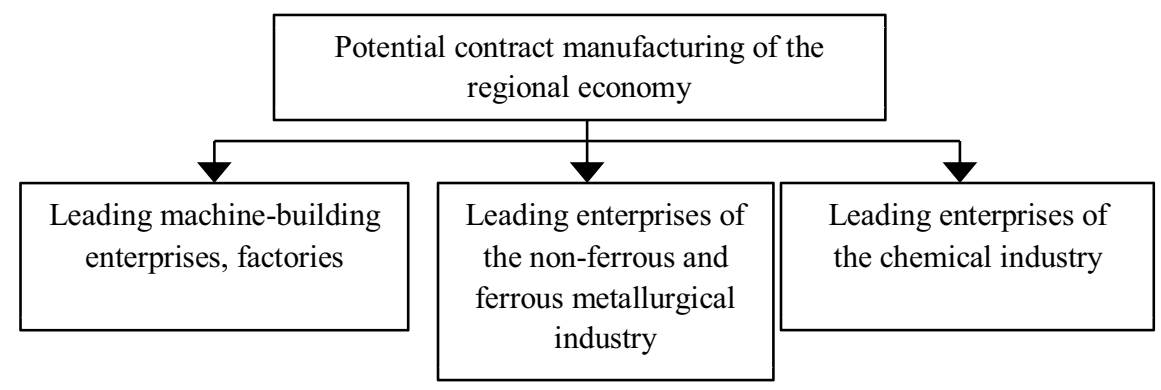

Fig. 2. Potential contract manufacturing that can be developed in regional economic systems.

The activities of the consulting center will focus on providing entrepreneurs with advice and guidance on the economic and organizational aspects of doing business entrepreneurship.

The activities of business incubators will be aimed at the gradual acceleration of business ideas.

In parallel with the dynamic development of small and medium-sized business entrepreneurship in regional economic systems, it is important to create - logistics hubs.

The logistics hub will provide services to entrepreneurs in the field of transport and material logistics, create optimal conditions for the transportation and storage of goods. 
For the interaction of potential business entities, small and medium-sized enterprises with elements of infrastructure support and for the dynamic development of the infrastructure itself, it is necessary to use all the elements of investment support:

- profits of enterprises;

- funds for the development of entrepreneurship;

- second-tier banks;

- state investment funds.

As an activation of investments in priority entrepreneurial projects, the following can be created at the regional level:

- regional fund for financial support of START UP projects;

- a pool of potential investors.

Taking into account the sectoral problems of the development of small business and the sectoral specifics of the regions, sectoral scientific and technological parks (technoparks) can be developed in the areas in accordance with Figure 3.

Regional technoparks will make it possible to establish a direct and reverse relationship in the system "entrepreneurship - science - innovation", which in the long term will expand production capabilities to create competitive products with high added value in the business sector.

In a strategic perspective, in regional economic systems, a technopark can be created in the field of research and design of green energy technologies.

The main services of the above-mentioned sectoral scientific and technological parks will be concentrated in the following relevant and significant areas:

- providing entrepreneurs with lease of premises fully equipped with high-tech research and production equipment of the core business by sectors (petrochemistry, metallurgy, mechanical engineering, agriculture);

- support of research and development work in small and medium-sized businesses in conjunction with regional higher educational institutions, an entrepreneurial university.

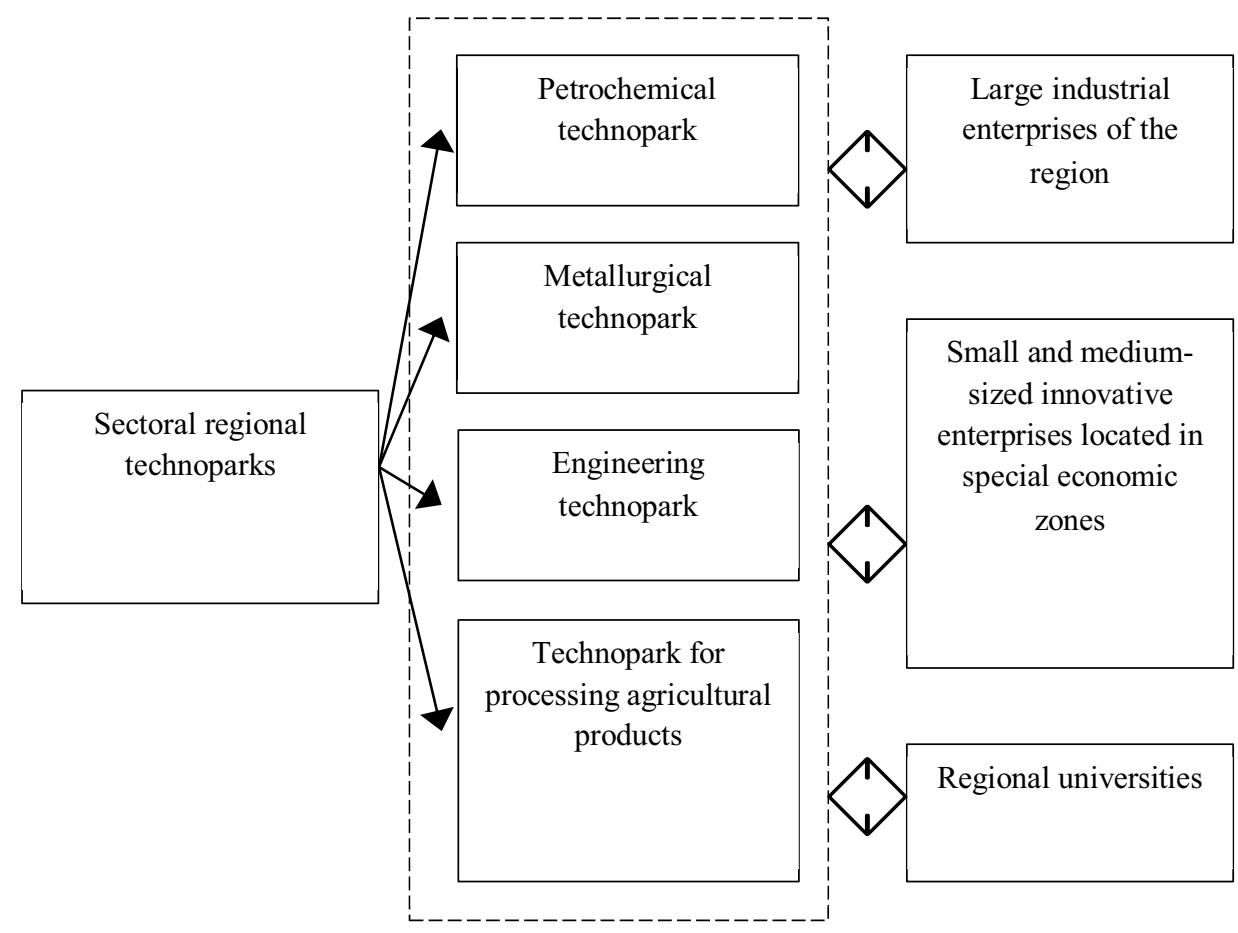

Fig. 3. The main areas of creation of regional industrial technoparks in Pavlodar region. 


\section{Results}

In the process of investing in the electronic industry, the main supreme governing body of science and technology parks will be the supervisory board, which will include the founders of technology parks - leading large industrial enterprises, as well as leading regional universities.

The presence of universities and representatives of industrial enterprises in the supervisory board should play the role of integration of small and large business.

As a result, the optimal and logically correct form of ownership of technoparks is a public-private partnership, a joint-stock company.

The creation of sectoral regional technoparks will require investments in a total volume of about 1.5 billion tenge per region.

The total investment costs for the creation of sectoral technology parks will take place in the following areas:

- investments in fixed assets (fixed production assets);

- investments in working capital (working capital of the enterprise);

- investment in human capital.

An approximate estimate of the total investment costs in the creation of the Petrochemical (chemical and technological) regional park is presented in Table 1.

Table 1. Approximate estimate of the total investment costs in the creation of the Petrochemical (chemical-technological) regional park.

\begin{tabular}{|c|c|c|}
\hline Name of investment costs & Value, tenge & $\begin{array}{l}\text { Investment } \\
\text { structure, \% }\end{array}$ \\
\hline $\begin{array}{l}\text { Investments in fixed capital (fixed production } \\
\text { assets), including: }\end{array}$ & 338719219.84 & 88.67 \\
\hline $\begin{array}{l}\text { - investments in basic research and technological } \\
\text { equipment, tenge }\end{array}$ & 140489539.84 & 36.78 \\
\hline $\begin{array}{l}\text { - investments in infrastructure development, } \\
\text { construction and installation works, tenge }\end{array}$ & 198229680.00 & 11525.81 \\
\hline Investments in working capital, tenge & 41560903.21 & 10.88 \\
\hline $\begin{array}{l}\text { Investments in HR resources (training, retraining } \\
\text { of industrial and production personnel) }\end{array}$ & 1719876.95 & 0.45 \\
\hline $\begin{array}{ll} & \text { Total } \\
\end{array}$ & 382000000.00 & 100.00 \\
\hline
\end{tabular}

The calculation of investments in fixed assets (fixed production assets) is carried out in two ways:

- calculation of investments in the main research and auxiliary technological equipment;

- calculation of investments in construction and installation works, focused on the formation of the infrastructure of the scientific and production process.

The cost estimate for the construction and installation works is presented in Table 2.

Table 2. Estimated cost of construction and installation works.

\begin{tabular}{|c|c|}
\hline Type of construction and installation works & $\begin{array}{l}\text { Cost estimate, } \\
\text { tenge }\end{array}$ \\
\hline Construction of the main scientific and laboratory complex & 74000000.00 \\
\hline $\begin{array}{l}\text { Construction of auxiliary facilities (hangar-type cold warehouse, } \\
\text { administrative office, canteen, laboratory building) }\end{array}$ & 30494550.00 \\
\hline Construction of energy facilities & 38661230.00 \\
\hline Construction of a communication automation facility & 12225900.00 \\
\hline $\begin{array}{l}\text { Construction of water supply and sewerage facilities, heat supply, } \\
\text { compressed air compressor unit, on-site facilities }\end{array}$ & 38778000.00 \\
\hline Improvement and gardening of the territory & 4070000.00 \\
\hline Total & 198229680.00 \\
\hline
\end{tabular}


Total investment in fixed assets can be calculated in accordance with Formula 1.

$$
\mathrm{I}_{\mathrm{FC}}=\mathrm{I}_{\mathrm{TE}}+\mathrm{I}_{\mathrm{CIW}},
$$

where $\mathrm{I}_{\mathrm{FC}}$ - investments in fixed capital;

$\mathrm{I}_{\mathrm{TE}}$ - investment in technological equipment;

$\mathrm{I}_{\mathrm{CIW}}$ - investments in construction and installation works.

The total investment in fixed assets will be

$$
\mathrm{I}_{\mathrm{FC}}=140489539.84+198229680=338719219.84 \text { tenge }
$$

The calculation of investments in HR-resources is determined on the basis of planning the number of leading scientific personnel of the technopark, administrative and managerial personnel, the general need for training and advanced training of personnel.

Investments in HR resources will be focused on training and advanced training of the technopark personnel.

The calculation of investments in training and advanced training of the scientific and production personnel of the technopark is presented in Table 3.

Table 3. Calculation of investments in training and advanced training of industrial and production personnel.

\begin{tabular}{|l|c|}
\hline \multicolumn{1}{|c|}{ Indicators } & Value \\
\hline $\begin{array}{l}\text { Number of research and production personnel focused on } \\
\text { training and advanced training, people }\end{array}$ & 4 \\
\hline Time budget for advanced training, hours & 72 \\
\hline Cost of training, advanced training, tenge / hour & 3500 \\
\hline Total investments in training and advanced training, tenge & 1719876.95 \\
\hline
\end{tabular}

\section{Conclusions}

In total, one-time investments in HR resources will amount to 1,719,876.95 tenge.

With the total volume of investments in the creation of business infrastructure, the return on investment should be at least $20 \%$ with a payback period of five years.

The implementation of regional projects to improve the infrastructure for supporting entrepreneurship based on the principles of creating industrial technology parks will allow:

- purposefully increasing the degree of participation of entrepreneurs in innovative activities;

- increasing the degree of participation of small and medium-sized businesses in the creation of new small enterprises in priority sectoral areas;

- creating an organizational and economic basis for the integration of small, medium and large businesses.

- deepening the specialization of the region in the manufacturing industry with its focus on import substitution.

Summing up, we can conclude that the proposed economic model of infrastructural support for entrepreneurial activity will improve the parameters for the effective use of the business potential of the regions, both in terms of individual qualitative and quantitative parameters.

\section{References}

1. On the approval of the State Program for Support and Development of Business "Business Action Plan 2020". Resolution of the Government of the Republic of 
Kazakhstan dated August 25, 2018 No. 522, http://adilet.zan.kz/rus/docs/P1800000522

2. Business support programs, https://damu.kz/programmi/

3. N.Y. Ryazanova, A.V. Sharkova, N.E. Lobzhanidze, E.V. Subbotina, O.E. Matyunina, International Journal of Recent Technology and Engineering 8(1), 2691-2695 (2019) ISSN: 22773878.

4. Y.V. Morozyuk, A.V. Sharkova, I.A. Merkulina, O.N. Vasilyeva, Journal of Environmental Management and Tourism 8.3(19), 507-515 (2017) DOI: 10.14505/jemt.v8.3(19).02.

5. I.A. Markina, A.V. Sharkova, M.Y. Barna, International Journal of Entrepreneurship 22(3), 13 (2018) ISSN: 10999264

6. E. Karieva, L. Akhmetshina, A. Mottaeva, E3S Web of Conferences 217, 07008 (2020) https://doi.org/10.1051/e3sconf/202021707008

7. L. Akhmetshina, A. Mottaeva, E3S Web of Conferences 210, 13034 (2020) https://doi.org/10.1051/e3sconf/202021013034

8. L. Akhmetshina, A. Mussina, S. Izmaylova, IOP Conf. Series: Earth and Environmental Science 403, 012168 (2019) doi:10.1088/1755-1315/403/1/012168

9. T. Kreydenko, M. Chernyaev, E. Grigorieva, A. Korenevskaya, International Journal of Energy Economics and Policy 10(2), 504-511 (2020) DOI: 10.32479/ijeep. 9083

10. A. Rementsov, N. Lebedeva, O. Kirichenko, E3S Web of Conferences 164 (2020) DOI: $10.1051 / \mathrm{e} 3$ sconf/202016410039

11. E.M. Deyanov, N.A. Kharitonova, IOP Conference Series: Materials Science and Engineering 976 (2020) DOI: 10.1088/1757-899X/976/1/012034 